\title{
Л.В. ПАНІНА
}

Львівський національний медичний університет ім. Данила Галищького

Lyubapanina@gmail.com

\section{Особливості розвитку адаптації організму за умов експериментальної гострої гіпоксії залежно від вихідного рівня вегетативного забезпечення}

Поширення киснедефіцитних станів, у т.ч. екстремальних, доводить гостру потребу поглибленого дослідження механізмів постгіпоксичної адаптації. Водночас експериментальне моделювання умов киснедефіциту забезпечує можливість програмованого контролю формування необхідного типу пристосувальної реакції на певному рівні реактивності організму. Його характер визначається не лише силою та специфікою подразника, але й адаптаційним потенціалом відповідної фізіологічної системи $[3,4]$.

(C) Паніна Л.В., 2016 
Мета дослідження. Вивчити механізми розвитку адаптивних реакцій організму за впливу гострої гіпоксії у системах із різним вихідним функціональним станом вегетативної регуляції.

Матеріали й методи дослідження. Здійснювали запис кардіоінтервалограми нелінійних статевозрілих білих щурів-самців із використанням фотоплетизмографічного перетворювача, фіксованого біля основи хвоста [1, 2]. Щурів знерухомлювали у природний для них спосіб, відтворюючи властивий для даного виду тварин “нірковий” рефлекс. Для цього їх поміщали в універсальну плексигласову камеру, форма якої відповідала будові тіла щурів, накривали ії темною щільною оксамитовою тканиною для усунення дії зайвих подразників; це давало змогу тварині заспокоїтись і забезпечувало стабілізацію показників. Аналіз варіабельності серцевого ритму (ВСР) здійснювали у діапазонах спектра: LF $(0,015-0,25)$ Гц, MF $(0,25-0,75)$ Гц, HF $(0,75-3,0)$ Гц. Гіпоксичну гіпобаричну гіпоксію з 10 -хвилинним періодом відтворювали барокамерним “підняттям" щурів деяких груп на умовну “висоту” 6000 і 9000 м над рівнем моря. За нормо- і гіпоксичних умов застосовували блокатори М-холінорецепторів - атропін дозами 0,4 i 2,0 мг/кг та $\beta$-адренорецепторів - пропранолол дозами 2 і 5 мг/кг. Щури деяких груп після введення блокаторів підлягали 10 хв впливу екстремальної гіпоксії (9000 м). Парні порівняння середніх проводили за $t$-критерієм Стьюдента. Відмінності вважали достовірними за рівня значимості $p<0,05$.

Результати дослідження та їх обговорення. Введення контрольним тваринам атропіну та пропранололу спричинило відповідно збільшення і зменшення ЧСС, як і очікували (рис. 1). Водночас гіпоксичний вплив у інтактних щурів та за попереднього застосування блокаторів реалізувався відсутністю вірогідних змін ЧСС (рис. 2).

Ритм серця є універсальною оперативною реакцією цілісного організму на різні впливи та характеризує особливості вже сформованого вегетативного балансу. Завдяки блокаторам вегетативного контролю роботи серця можна модифікувати вихідний рівень вегетативного забезпечення з метою подальшого аналізу особливостей розвитку адаптивних змін за дії стресових чинників. Вони слугують своєрідним функціональним навантаженням, яке дозволяє проводити тестування активності відповідних регуляторних ланок до та після їх дії. Своєю чергою аналіз ВСР із застосуванням різних методичних підходів дає змогу визначити специфіку змін тонусу відповідних ланок АНС для підтримання належної ЧСС.

Зокрема, щодо параметрів варіаційної пульсометрії, введення атропіну контрольним щурам виявилось дозозалежним збільшенням індексу напруження регуляторних систем (SI) (рис. 3). Цей показник характеризує підвищення тонусу симпатичної ланки - центрального контуру та вказує на напруження адаптації. Отримані зміни підтверджувались стабілізацією ритму, збільшенням кількості однотипних за тривалістю інтервалів, тобто амплітуди моди (AMo), зі зниженням Мо. Дія пропранололу не спричинила до суттєвих вірогідних змін SI та Mo.

У разі введення двох доз атропіну спостерігали вірогідне зниження статистичних показників, зокрема RMSSD, у більшій дозі також SDNN, що характеризують насамперед активність парасимпатичної ланки регуляції. Застосування пропранололу призвело лише до тенденційного їх підвищення.

Водночас вплив гіпоксії на “висоті” 9000 м реалізувався вірогідним збільшенням усіх статистичних величин у межах $1,5-1,7$ разу (рис. 4). За поєднаної дії атропіну та гіпоксії відбулося тенденційне зниження цих параметрів BCP, окрім SDNN за меншої дози атропіну. Попередне до гіпоксії застосування пропранололу супроводжувалось вірогідним 
дозозалежним підвищенням усіх статистичних параметрів, що свідчить про активацію парасимпатичної регуляції. За високої дози пропранололу та гіпоксії характер змін фактично нагадував ефект впливу самої гіпоксії на “висоті" 9000 м.

Із уведенням блокаторів змінився також характер спектральних коливань. Зокрема, при застосуванні атропіну зі збільшенням дози спостерігали зменшення загальної потужності спектра (ТР) та різною мірою абсолютних величин усіх його складових (див. рис. 1).

За введення пропранололу контрольним тваринам у меншій дозі зафіксовано збільшення ТР, у межах $30 \%$, проте зниження на $\sim 46 \%$ зі збільшенням дози препарату. Характерно, що збільшення ТР відбувалося за рахунок активації усіх його складових. Проте зниження, виявлене за дії пропранололу у більшій дозі, реєстрували внаслідок зменшення абсолютних значень $\mathrm{HF}$ та MF, за відсутності вірогідних змін LF (див. рис. 1).

Високо вірогідне збільшення інтенсивності ТР реєстрували також за умов гіпоксії, відповідно на “висотах" 6000 і 9000 м, у 2,3 і 3,7 разу (див. рис. 2). Зміни загальної потужності визначалися яскраво вираженим, залежним від інтенсивності гіпоксії, збільшенням усіх складових спектра, найбільшою мірою НF та MF.

Загалом зміни параметрів ВСР за дії різної міри гіпоксії мали односпрямований, дозозалежний характер. При цьому виявлено тенденцію до порушення вегетативного гомеостазу - надмірну активацію дихальної періодики кардіоритму та ерготропних - енергомобілізуючих систем.

Попередня до гіпоксії дія атропіну зумовила зниження загальної потужності (ТР) і односпрямоване - усіх його складових (див. рис. 2). Виняток становив для абсолютних значень LF за більшої дози атропіну при гіпоксії. За дії двох доз атропіну у поєднанні з гіпоксією відносні значення LF були значно вищими порівняно з іншими параметрами спектра, а також щодо аналогічних показників за дії самої гіпоксії (див. рис. 2).

Загалом, згідно з даними спектрального аналізу, попереднє введення атропіну нівелювало гіпоксичний вплив на активність досліджуваних нами регуляторних механізмів.

Попереднє до гіпоксії введення пропранололу зумовило підвищення спектра коливань, яке досягнуло несподівано високих значень у разі збільшення дози препарату, навіть вищих за дії самої гіпоксії на “висоті" 9000 м (див. рис. 2). Водночас при попередньому застосуванні меншої дози блокатора та гіпоксії ці показники були значно нижчі, ніж аналогічні за умов лише гіпоксії.

Вплив великої дози пропранололу та гіпоксії потенціював чітко протилежні зміни спектра, порівняно з такими за дії самого $\beta$-адреноблокатора, водночас показово посилив вплив гіпоксії на “висоті" 9000 м стосовно активності систем регуляції серцевого ритму.

Виявлений нами потенціюючий вплив пропранололу щодо стресреалізуючих механізмів у досліджувані терміни може мати пояснення в межах реципрокного задіяння при цьому альфа-адренорецепторів.

Висновки. Зміни досліджуваних параметрів ВСР за дії, поєднаної з уведенням блокаторів короткотривалої гострої гіпоксії, слугували інформативними критеріями для оцінки вже сформованих адаптаційних можливостей систем регуляції, а також стійкості вегетативного гомеостазу, визначення меж адаптаційного резерву. 

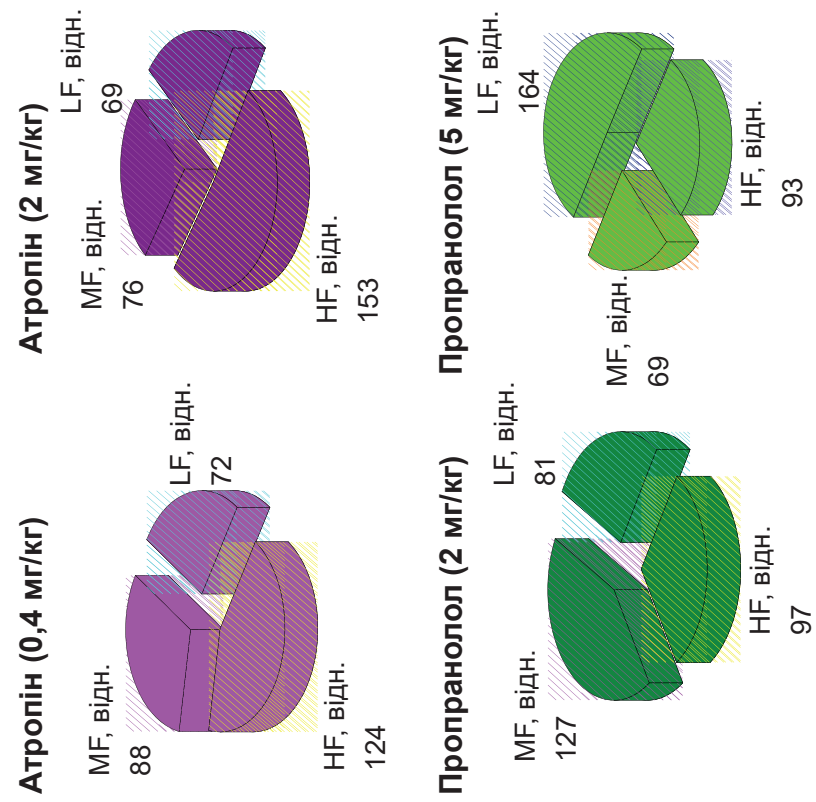

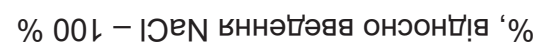



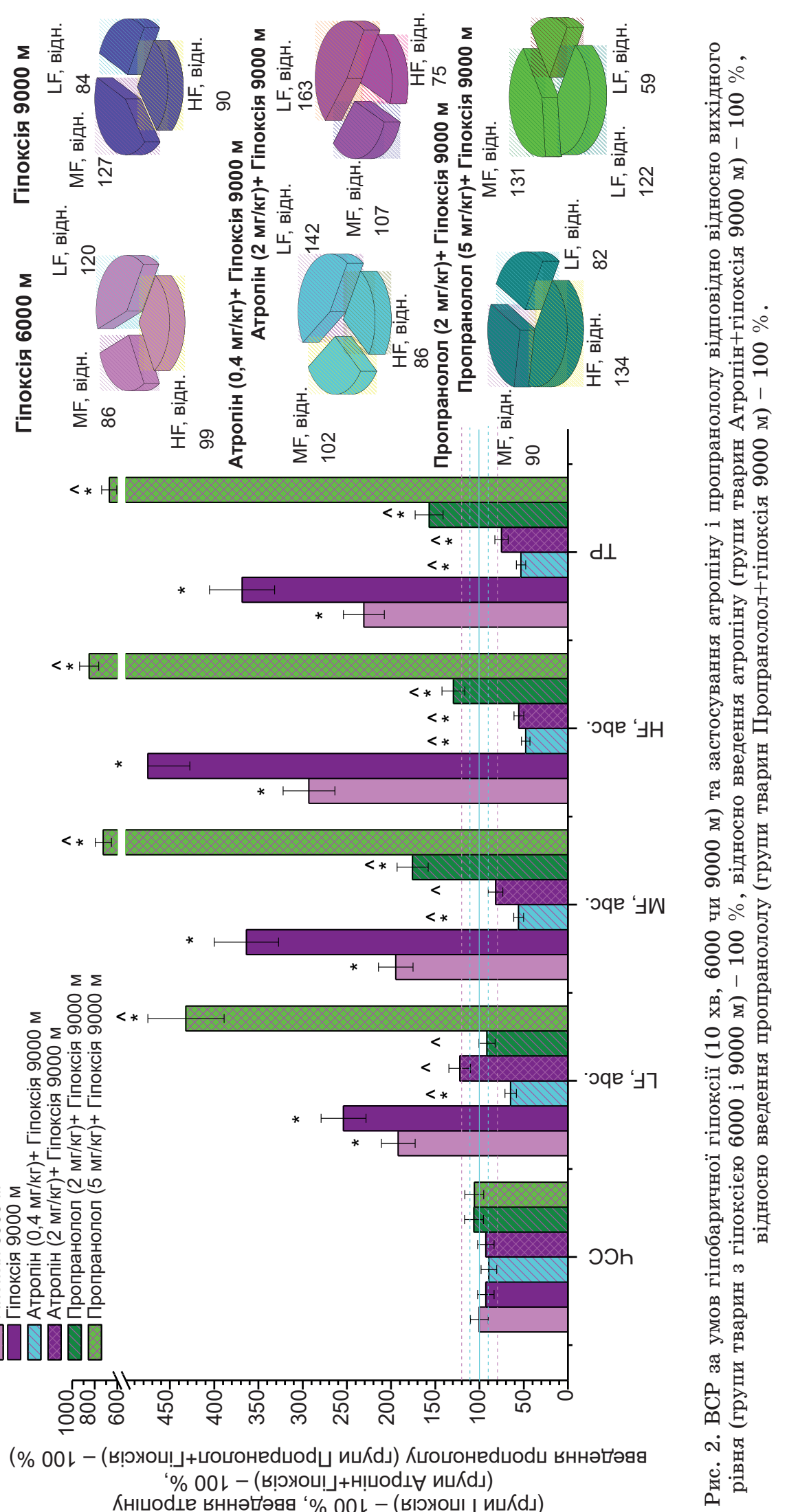


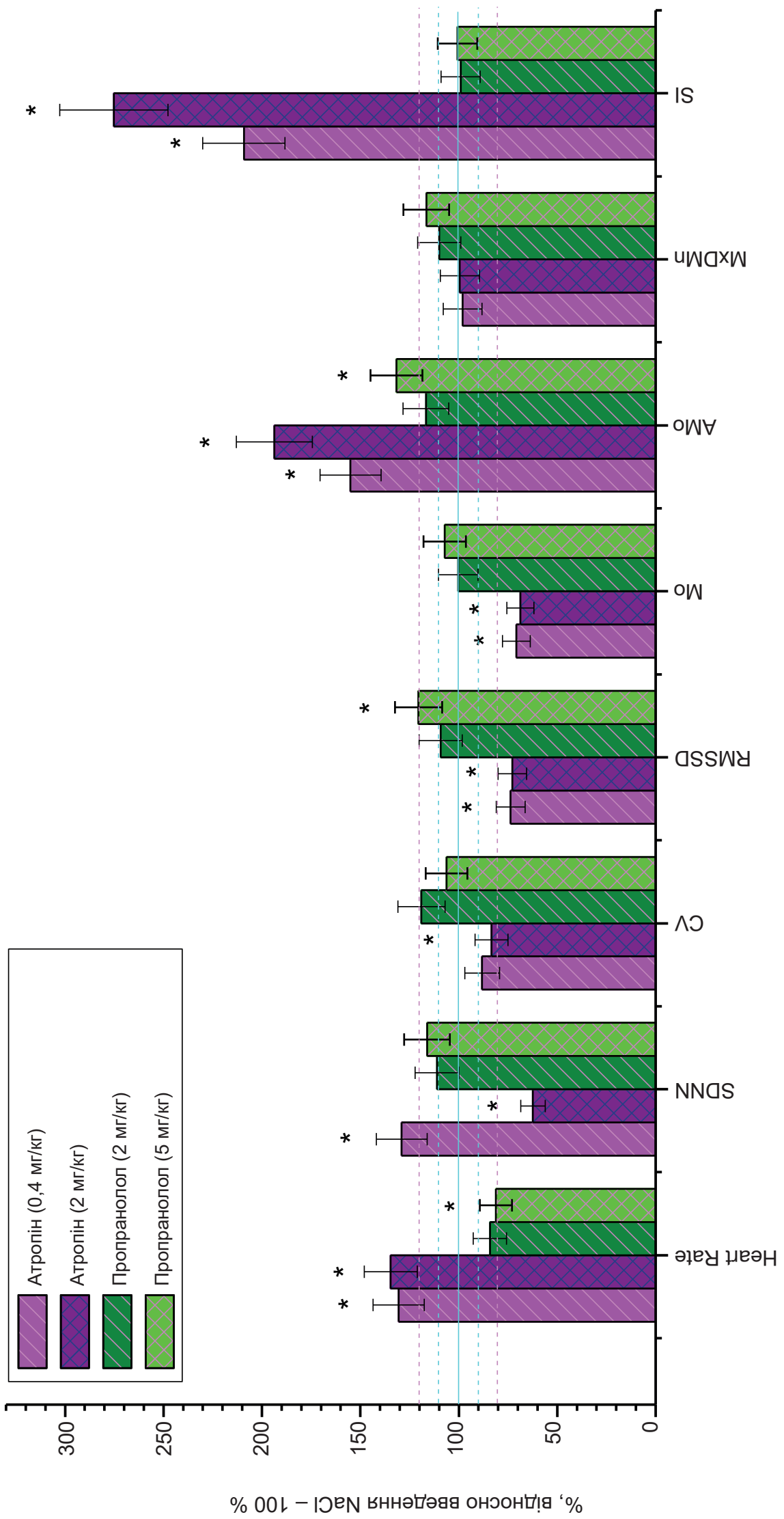




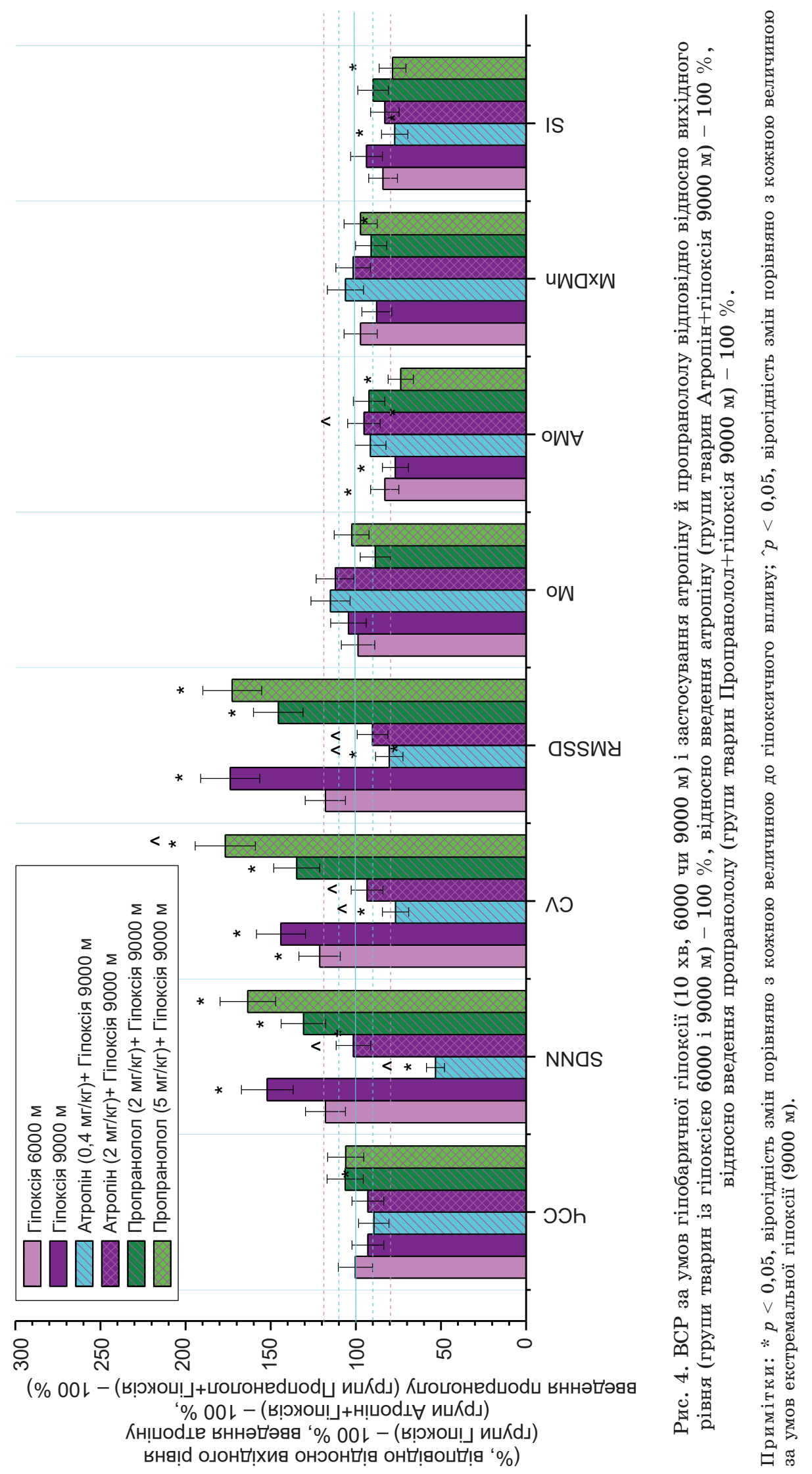




\title{
СПИСОК ЛІТЕРАТУРИ
}

1. Метод оцінки функціонального стану експериментальних тварин на основі аналізу варіабельності серцевого ритму/ М.Р. Гжегоцький, Л.В. Паніна, С.М. Ковальчук [та ін.] // Матеріали 3-ї міжнар. наук.-практ. конф. “Проблеми та перспективи методичних підходів до аналізу стану здоров'я” (26-27 берез. 2009 р., Луганськ). Український медичний альманах. - 2009. - Т. 12, № 2 (додаток). - С. 187-190 (The method of estimation of experimental animals' functional state on the basis of heart rate variability analysis / M. Gzhegotsky, L. Panina, S. Kovalchuk [et al.] // Proceedings of the Third International Scientific conference "Problems and prospects of the methodological approaches to the analysis of health" (March 26-27, 2009, Lugansk). - Ukrainian medical almanac. - 2009. - Vol. 12, N2 (annex). - P. 187-190). 2. Meтод неінвазивного визначення тривалості серцевого циклу у щурів / М.Р. Гжегоцький, Є.В. Сторчун, Л.В. Паніна [та ін.] // Практична медицина. - 2009. - Т. 15, № 4. - С. 47-50 (Noninvasive method of determining the duration of cardiac cycle in rats / $M$. Gzhegotsky, E. Storchun, L. Panina [et al.] // Practical Medicine. - 2009. - Vol. 15, N 4. - C. 47-50). 3. De Ferrari G.M. Vagus nerve stimulation: from pre-clinical to clinical application: challenges and future directions / G.M. De Ferrari, P.J. Schwartz // Heart Fail. Rev. 2011. - Vol. 16. - P. 195-203. 4. Lymperopoulos A. Adrenergic nervous system in heart failure: pathophysiology and therapy / A. Lymperopoulos, G. Rengo, W. Koch // Circ. Res. - 2013. - Vol. 113. - P. 739-753.

Стаття надійшла до редколегії 12.08.2016

\section{Features of Development of Organism Adaptation under the Conditions of Experimental Acute Hypoxia Depending on Baseline of Autonomic Support}

\author{
L. PANINA \\ Danylo Halytskyi Lviv National Medical University
}

In this study we have investigated the mechanisms of adaptive reactions of the organism under the conditions of acute hypoxia exposure in systems with different initial functional state of autonomic regulation. We conducted the record of the cardiointervalogramm of white male rats and the analysis of heart rate variability.

During the introduction of atropine to the control group of rats, we could observe the dose-dependent increase of the index of tension of regulatory systems. This index characterizes the increase of the sympathetic system tone. The resulting changes were verified by stabilization of heart rate and the increased number of isochronous intervals. Effects of propranolol did not result in significant changes of those parameters. During the introduction of atropine in two doses, significant decrease of the statistical parameters was observed. That mainly characterizes the activity of the parasympathetic regulation. The application of propranolol led only to their tendentious increase.

The effect of hypoxia at a "height" of $9000 \mathrm{~m}$ developed significant increase of all statistical parameters. The combined effect of atropine and hypoxia caused tendentious decrease of the parameters of heart rate variability. Application of propranolol prior to hypoxia was accompanied by significant dose-dependent increase of all statistical parameters, indicating the activation of parasympathetic regulation. Under the condition of the applying of high dose of propranolol and hypoxia, the character of changes resembled the effect of influence of hypoxia itself at a "height" of $9000 \mathrm{~m}$.

During the application of atropine with the increasing of dose, we observed the reduction of the total spectral power (TP) and varying degrees of the absolute values of all its components. The introduction of propranolol to the control animals at lower dose manifested the increase of TP, within $30 \%$. However, it was reduced by $\sim 46 \%$ with the increase of the medicationdose.

Highly significant increase of TP intensity was registered also under the condition of hypoxia. The changes of the total power were determined by the increase of all components of the spectrum, mostly MF and HF. We could observe the tendency to violation of the vegetative homeostasis, viz. the excessive activation of respiratory component of cardiorhythm and ergotropic energy mobilizing systems.

Application of atropine prior to hypoxia led to decrease of the total power and unidirection of all its components. The exception was for the absolute values of LF under the introduction of large dose of atropine during hypoxia. During the action of atropine in 
two doses combined with hypoxia, relative values of LF were significantly higher compared with other parameters of spectrum, as well as with similar parameters affected by hypoxia itself. According to the spectral analysis, the introduction of atropine prior to hypoxia leveled hypoxic effect on the activity of the regulatory mechanisms that we studied.

Introduction of propranolol prior to hypoxia caused the increase of spectral fluctuations that reached unexpectedly high values with the increase of medication dose, even higher than the effect of hypoxia itself at a "height" of $9000 \mathrm{~m}$. However, with the previous use of a smaller dose of the blocker and hypoxia, those parameters were much lower compared to similar ones affected by hypoxia itself. It is characteristic that the effect of propranolol in its high dose and hypoxia potentiate quite opposite spectral changes, compared to those with the effect of $\beta$-blockers. However, it significantly increased the effect of hypoxia at a "height" of $9000 \mathrm{~m}$ concerning the activity of the system of cardiac rhythm regulation.

Key words: functional state of autonomic regulation, heart rate variability, hypobaric hypoxia. 